\title{
Meta-Analysis of Teams Games Tournament Learning Model with Spinning Wheel Media-Based on Local Wisdom Toward Students' Learning Outcomes
}

\author{
Devita Kurniawati1 ${ }^{1}$ *, Mohammad Taufiq ${ }^{2}$, Suharmono Kasiyun ${ }^{3}$, Nafi'ah
}

1,2,3,4 PGSD FKIP Universitas Nahdlatul Ulama Surabaya

\begin{tabular}{l} 
A R T I C L E I N F 0 \\
\hline Article history: \\
Received 10 February \\
2020 \\
Received in revised \\
Form 01 March 2020 \\
Accepted 08 May 2020 \\
Available online 30 \\
August 2020 \\
\hline
\end{tabular}

Keywords:

Learning outcomes,

Science, Spinning wheel, TGT, Local wisdom difference from before and after the use of the learning model that assisted team's tournament games wheel media in science subjects.

\begin{abstract}
A B S T R A C T
Research that examines the effect of cooperative learning teams games tournament types on student learning outcomes has been done a lot, but the results of these studies have not received further study to be summarized and tested again the effectiveness of the effect of the learning model used. This study aims to analyze the effect of the use of a team games tournament type cooperative learning model with spinning wheel media-based local wisdom on the learning outcomes of elementary school students. The method used in this research is meta-analysis. The collection of data through online searches using the Google Scholar platform as many as 15 articles were collected with the details of 10 articles representing the learning models of team's games tournaments and spinning wheel media while the remaining 5 articles are educational articles based on local wisdom. All articles are then analyzed with differences and similarities in data and then reprocessed using SPSS Version 25 using paired sample t-test and showing the Sig. (2-tailed), i.e. $(0,019)<\alpha$ (0.05). So, $\mathrm{HO}$ is rejected and it can be concluded that there is a significant
\end{abstract}

\section{Introduction}

Education is a conscious and planned effort to realize learning by the learning process so that students actively develop their potential, to have spiritual spiritual strength, self-deepening, personality, intelligence, noble character and skills that are it needs itself, society, nation and country. Education is one of the pillars in the state that can underlie the progress of a nation, With education, the process of forming quality human resources can be realized. So, it must also be in line with improving the quality of the existing education system in Indonesia (Khohar et al., 2016; Komarudin, 2018).

Improving the quality of education quality must also be aligned with the main function of education, which is to develop capabilities and shape the character and civilization of a dignified nation in the context of intellectual life of the nation. Based on this educational function, the teacher's role is a determinant of the success of education and learning missions in schools. The teacher is responsible and organizes, directs, and creates a conducive atmosphere (Fauzi et al., 2019; Suardi, 2012). In the above quotation it has been explained that in the field of education through the teacher as a facilitator in order to realize the goals of education, the learning process is needed so that later the goals in national education can be realized. The learning process is an interaction activity between students and teachers that takes place in the classroom. In this interaction, there is a transfer of knowledge from teacher to student. Supporting tools are needed in the learning process so that it runs optimally, especially if it is associated with natural science learning, it needs learning media related to the material delivered by the teacher (Sholeh et al., 2019).

Learning media are media that are used in learning, which include teaching aids in teaching as well as a means of carrying messages from learning sources to learning message recipients, namely students (Utami et al., 2019). According to (Suryani \& Agung, 2012), it is clear that learning media is a media of education that can help teachers in the transfer of knowledge to students, in addition to being an appropriate media teacher's tool also can educate their students. The use of instructional media that will later be applied in the learning process must also be in accordance with student interests. One effort to 
create a learning atmosphere that is fun, lively and relaxed in the learning process of students is to invite students to play while learning (Purwanto, 2010; Syarani, 2019).

However, students' learning outcomes in Indonesia today need to be improved. The fact shows that the learning outcomes in Indonesia are currently in the low category based on the PISA study. PISA study measures students' cognitive knowledge. The results of PISA (Program for International Student Assessmen) shows that Indonesia has a low literacy skill with a score of 403 below the average score in OECD countries, namely 493 (Listyarini et al., 2018; Fauzi et al., 2019). These results indicate that the quality of learning process in Indonesia needs to be developed to be able to improve students' preformance. The learning process that is curretly happening is not related to the real-context, actual and factual problem are rarely used in the learning process, the learning materials in elementary school is not focus and the learning which goes on as if only in anticipation of the student for the exam (Suaeb et al., 2017). This opinion indicates that current learning process tends to be less effective, causing student learning outcomes in elementary schools below. This indicates the need for improvement and improvement in the learning process in elementary schools. Although currently there are many types of research and innovative methods in the learning process, this condition can occur because the learning process that takes place does not maximize the ability of students in critical thinking to explore, understand and solve problems experienced in real life even though they apply a learning model. If this is allowed to happen, it will harm the output obtained by students, especially on understanding and learning outcomes. Improving the quality and effectiveness of learning process in elementary schools can be done with a variety of efforts, one of which is through the application of the cooperative model (Widhiastuti \& Fachrurrozie, 2014; Syarani, 2019). This learning model is based on constructivism theory which directs students to be able to construct their knowledge through the collaboration process. The statement explains that this cooperative model can make students build their understanding or knowledge through collaboration created from learning activities.

According to observations at SDI Kyai Amin data obtained that the learning process in class uses conventional methods with a scientific approach which if in science subjects should use several methods and learning models. Cooperative models should be given to students so that the process of discussion and delivery of opinions in front of the class can run well. Whereas for learning media only use the media of images printed on paper by the teacher so that the achievement of students' imagination is less than the maximum, and the learning outcomes are also less than optimal. In the delivery of learning materials, especially in areas of learning that are quite difficult, including science, it looks so great the role of learning media as a means of conveying knowledge to students optimally and attractively. Because if the delivery of material is less attractive to students, students pay less attention to the material delivered especially if the material is at a difficult level and requires deeper understanding.

Due to the situation in SDI Kyai Amin, one of the cooperative learning models that will be used is the TGT ( Teams Games Tournamnet) model with a combination of learning media for spinning local wisdom wheels which will be integrated through natural resource materials. TGT learning model is a cooperative learning model based on group environment with real and structured interaction. According to (Slavin, 2015), TGT is a cooperative learning model that uses academic tournaments and uses quizzes, where students compete as their team representatives with other team members whose previous academic performance is equal to them. In line with the opinion of (Faturrahman, 2015) Cooperative learning of the TGT model is one type or model of cooperative learning that is easily implemented and implemented by students with low or high levels of education.

It can be said that the TGT learning model (Teams Games Tournamnet) is a quiz tournament on certain subjects that can be used at all levels of education. So the TGT learning model is one type of cooperative learning model that uses tournament games at the end of sub-chapters and each team member has an equivalent level of academic performance. This learning model can train a sense of responsibility, kinship and mutual support between team members, besides that unconsciously, students will begin to understand and learn about the material being taught so that during the tournament he and the team can win the match easily while also being able to improve student learning outcomes to exceed KKM. Usually a team consists of 5 students. Also with the help of the spinning wheel media, the activities of this tournament will be even more interesting and more challenging (Fauzi et al., 2019).

The TGT learning model is a model that can affect student learning outcomes. Research conducted by (Listyarini et al., 2018; Utami et al., 2019; Komarudin, 2018) states that there is a positive influence on student science learning outcomes after applying the TGT learning model. It can be seen from the learning outcomes that are applied to the TGT learning model higher than the learning outcomes of students who do not use the TGT learning model. Research data regarding the TGT learning model have been widely published, however, further research on the research data has not been widely carried out. The research data requires further research to be summarized and reassessed for its effectiveness so that it can 
strengthen or create new studies from the results of previous research. However, until now there has been no meta-analysis research on the effect of TGT learning models on learning outcomes at the elementary school level. Based on these descriptions and problems, the researcher will examine the effect of the TGT learning model on student science learning outcomes in elementary schools. This study aims to analyze the effect of the use of a team games tournament type cooperative learning model with spinning wheel media-based local wisdom on the learning outcomes of elementary school students.

\section{Methods}

This study was a quantitative research uses a type of literature review. Literature study is a search and exploration of literature studies that have been done by people on a particular topic or issue and can be accessed from several journals, books and writings from other publications related to the research topic (Amri, 2016). The method in this study uses meta-analysis, meta-analysis is research that uses numbers and statistical methods that can be tested through SPSS and from the results of several studies, used to combine and explore as much information as possible from the data obtained. The statistical data used relates to the effect of TGT learning model on student science learning outcomes in elementary schools.

The research subjects in this study were articles from journals published nationally with characteristics, namely; (1) written by students and general researchers; (2) research was carried out in Indonesia; (3) the research was conducted at the primary school level; (4) the research used was from 2010-2019; (5) research subjects in the form of the influence of guided inquiry learning models on science learning outcomes of elementary students; (6) the articles used must include research data such as the mean, median, mode, and standard deviation; (7) articles published in a journal accredited by Sinta. This study used two variables, namely the independent variable and the dependent variable. The independent variable in this study was the TGT learning model, while the dependent variable in this study was the learning outcome

\section{Result and Discussion}

The following are some research articles from search results related to the topics of the journals teams' games tournament, spinning wheel media and local wisdom. From the fifteen journal articles taken, the research data were obtained that there was an influence of the Teams Games Tournament learning model in improving student learning outcomes by using the wheel of local wisdom wheel media in Natural Science class IV in elementary school. The Teams Games Tournament learning model and the media wheel spin local wisdom has a positive influence that can increase motivation, interest, activity and also student learning outcomes that increase. The following below is the composition of the research articles used in this meta-analysis study:

Table 1. The Research Article

\begin{tabular}{|c|c|c|c|c|c|}
\hline \multirow{2}{*}{ No } & \multirow{2}{*}{ Research Topics } & \multirow{2}{*}{ Researcher } & \multicolumn{3}{|c|}{ Improved Learning Outcomes } \\
\hline & & & Before & After & Gain \\
\hline 1 & $\begin{array}{l}\text { Teams Games Tournament Learning } \\
\text { Model, IPS, Flash card, student learning } \\
\text { outcomes }\end{array}$ & (Rochanah, 2018) & 61.81 & 88.63 & 26.82 \\
\hline 2 & $\begin{array}{l}\text { Teams Games Tournament learning } \\
\text { model , Natural Sciences }\end{array}$ & $\begin{array}{l}\text { (Hakim \& Syofyan, } \\
\text { 2017) }\end{array}$ & 68.96 & 70 & 1.04 \\
\hline 3 & $\begin{array}{l}\text { Teams Games Tournament learning } \\
\text { model, learning outcomes, kingdom } \\
\text { animalia }\end{array}$ & $\begin{array}{l}\text { (Hikmah et al., } \\
\text { 2018) }\end{array}$ & 55,15 & 80.44 & 25.29 \\
\hline 4 & $\begin{array}{l}\text { TGT model, STAD, Student learning } \\
\text { outcomes }\end{array}$ & $\begin{array}{l}\text { (Yunanda \& } \\
\text { Sumarmin, 2018) }\end{array}$ & 70.89 & 80.22 & 9.33 \\
\hline 5 & Spinning wheel media, IPA & $\begin{array}{l}\text { (Ardiansyah, } \\
\text { 2017) }\end{array}$ & 64.33 & 78 & 13.7 \\
\hline 6 & $\begin{array}{l}\text { Question Wheel, student learning } \\
\text { outcomes }\end{array}$ & (Nisak, 2016) & 36.8 & 81.6 & 44.8 \\
\hline 7 & $\begin{array}{l}\text { Teams games tournament, improve } \\
\text { competences, }\end{array}$ & $\begin{array}{l}\text { (Damawan \& } \\
\text { Haryanto, 2018) }\end{array}$ & 63.3 & 83 & 19.7 \\
\hline 8 & Numbered head together, turn wheel & (Eeliana, et al., & 57.22 & 76.39 & 19.12 \\
\hline
\end{tabular}




\begin{tabular}{clllll}
\hline \multirow{2}{*}{ No } & \multicolumn{1}{c}{ Research Topics } & \multicolumn{2}{c}{ Researcher } & \multicolumn{3}{c}{ Improved Learning Outcomes } \\
\cline { 4 - 6 } & media, learning achievement & Before & After & Gain \\
\hline \multirow{2}{*}{9} & Teams games tournament, dice game & $\begin{array}{l}\text { (Widayanti \& } \\
\text { Slameto, 2019) }\end{array}$ & 57 & 72.1 & 15.1 \\
10 & $\begin{array}{l}\text { Teams Games Tournament learning } \\
\text { media, Natural Sciences }\end{array}$ & $\begin{array}{l}\text { (Wulandari \& } \\
\text { Regina, 2014) }\end{array}$ & 88.45 & 68.3 & 20.15 \\
\hline
\end{tabular}

Table 2. Paired Samples Statistic

\begin{tabular}{|c|c|c|c|c|c|c|}
\hline \multicolumn{7}{|c|}{ Paired Sample Statistic } \\
\hline & & Mean & N. & Std. Deviation & & \\
\hline \multirow{2}{*}{ Pair 1} & Sebelum & 62,3 & 10 & & 13,056 & 4,129 \\
\hline & Sesudah & 77,8 & 10 & & 6,443 & 2,037 \\
\hline
\end{tabular}

Table 2 data are the average results before and whose values have been rounded and tested through SPSS Version 25, the above data shows significant results between before and after using the teams games tournament learning model and combined with learning media, with an average gain in number 15.5 .

Table 3. Paired Samples Correlations

\begin{tabular}{ccccc}
\hline \multicolumn{4}{c}{ Paired Samples Correlations } \\
\hline & $\mathbf{N}$ & Correlation & Sig. \\
\hline Pair & Sebelum \& Sesudah & 10 & $-0,484$ & .156 \\
\hline
\end{tabular}

After the correlation test was performed using SPSS Version 25, the data in table 3 above shows the existence of correlations between the learning models for teams games tournamnet, the spinning wheel media and the results of science learning.

Table 4. Paired Samples Test

\begin{tabular}{|c|c|c|c|c|c|c|c|}
\hline \multicolumn{8}{|c|}{ Paired Samples Test } \\
\hline & & \multicolumn{5}{|c|}{ Paired Differences } & $\begin{array}{l}\text { Sig. (2- } \\
\text { tailed) }\end{array}$ \\
\hline & & \multirow{2}{*}{$\begin{array}{c}\text { The } \\
\text { mean }\end{array}$} & \multirow[t]{2}{*}{ Std. Deviation } & \multirow[t]{2}{*}{ Std. Error Mean } & \multicolumn{2}{|c|}{$\begin{array}{c}95 \% \text { Confidence Interval } \\
\text { of the Difference }\end{array}$} & \\
\hline & & & & & Lower & Upper & \\
\hline $\begin{array}{c}\text { Pair } \\
1\end{array}$ & $\begin{array}{c}\text { Sebelum } \\
- \\
\text { Sesudah }\end{array}$ & $-15,5$ & 17,129 & 5,417 & $-27,753$ & $-3,247$ & 0.019 \\
\hline
\end{tabular}

From the data in table 4 shows the Sig. (2-tailed), i.e. $(0,019)<\alpha(0.05)$. So, $\mathrm{H}_{0}$ is rejected and it can be concluded that there is a significant difference from before and after the use of the learning model teams tournament games that aided the media wheel in science subjects.

of the ten research articles above, all research results show a significant average increase in yield between before being treated and after being given treatment. That is, the learning model and instructional media used by the researchers in the above research article have a positive influence on student learning outcomes in elementary school.

The values of local wisdom culture today are less attention or even ignored in learning, especially learning science or science in schools (Suastra et al., 2011). This opinion is strengthened by the results of observations made by researchers about the lack of local wisdom values that are integrated into the learning process. The implementation of learning based on local wisdom will foster awareness to preserve the existing culture (Alwasilah, 2009). This can be done by integrating the values of local wisdom into learning in accordance with the existing content. So the integration of the values of local wisdom in the learning process in schools becomes important in addition to increasing knowledge and preservation of culture can also help students in understanding learning material that is in direct contact with the 
circumstances. As fast food and food from abroad hit the tongue of the people faster, globalization and modern lifestyles are the main driving factors (Khuzaimah \& Rohaeti, 2016; Emi, 2018). Therefore the need to maintain the characteristics of an area that is integrated with learning in schools so that students get a full insight of knowledge about local wisdom in their area also get an understanding of the material more easily because it is connected with the location where they live.

Such as local wisdom-based research conducted by (Kurniawati, 2019) with the title "Semanggi Suroboyo Kendung Benowo Village-Surabaya as a Source of Ethnopedagogy-Based Learning in Elementary Schools." In this study the local wisdom raised was the Surabaya clover plant commonly found on the edge of rice fields. This plant is usually eaten with a mixture of spices pecel on it. Clover plant is a typical Surabaya plant that has begun to disappear in the culinary circulation in Surabaya. Fast food and food from abroad hit the tongue of the people faster, globalization and modern lifestyles are the main driving factors. Therefore, it is necessary to maintain the special characteristics of food from an area that is integrated with learning in schools so that students get a full insight of knowledge about local wisdom in their area also get easier understanding of the material because it is connected with the location of residence.

As a pillar of the nation's young generation must know the culture and local wisdom of the nation which can be started from where he lives. The research method carried out by one of five researchers namely (Kurniawati, 2019) using ethnographic methods, researchers came directly to the semanggi village in Kendung Benowo Village, Surabaya, in order to obtain real data about the components in the clover plant. After doing the research there is a result that there are some matches between clover and some KD subjects in elementary schools. some suitable subjects are mathematics class 3 and 4 , science class 4, 5, and 6, social studies class 4 and 5, PPKn class 6, Indonesian class 2, 3, and 4, and the last is SBdP for class 1, 2, 3 and 4 . If you see so many matches that can be integrated in learning in elementary schools. In addition there are still many studies on local wisdom that produce a match between local wisdom in an area with learning in elementary schools.

The material chosen in my research is the natural resource of local wisdom which includes parks and forests in the city of East Surabaya. These parks and forests are natural resources that store many benefits for human, plant and animal life. Many of the people of Surabaya visit when they are on holiday weekend or the most visited on Saturdays and Sundays. Because of the large number of visitors who come it is right on target if the learning material available in primary schools is linked to places frequented by students. The parks and forests located in East Surabaya are local wisdom parks that only exist in Surabaya and not in other cities. Some of the parks and forests were indeed built for nature conservation and sports and children's play facilities. The list of parks and local wisdom forests that became the sample of this study included 7, namely Sakura Park, MERR Park, Gunung Anyar Magrove Forest, Wonorejo Mangrove Forest, Wonorejo Seed Garden, Bratang Seed Garden, Bamboo Forest. The park and forest will be integrated with natural resource material using the Teams Games Tournament learning model and also incorporated into the media of the spinning wheel which is a supporting tool for student understanding. The aspects used are the functions, advantages and characteristics of each park and forest in Surabaya. Based on the results of data analysis from SPSS above, it can be concluded that there is an effect of the Teams Games Tournament learning model on student learning outcomes aided by the media of the spinning wheel in natural science subjects of elementary school students, although there are differences in research articles in the education level, but the average learning outcomes show an upward trend the good one.

\section{Conclusion}

Based on the research results, there is a significant difference from before and after the use of the learning model teams who aided the media tournament games question wheel. The increase that occurred was enough to give a positive trend as a basis for research renewal that uses local wisdom as a companion to the material that is integrated into learning through the side of student life. From the article was taken earlier researchers mention that local wisdom can be adjusted with the basic competencies that exist so as not to deviate from the material being taught.

\section{References}

Alwasilah, Chaedar A, dkk. 2009. Etnopedagogi. Bandung: PT. Kiblat Buku Utama

Anggraini, L.G. (2019). Penerapan model pembelajaran TGT (teams games tournament) terhadap hasil belajar siswa pada mata pelajaran IPA kelas V SDN 101887 Bangun Sari Tanjung Morawa. 
Ardiansyah, M.Z.F., Mustaji. (2017). Pengembangan media permainan roda putar materi pokok ekosistem dalam mata pelajaran ilmu pengetahuan alam bagi siswa kelas V Sekolah Dasar. Universitas Negeri Surabaya

Damarwan, E.S., Haryanto., La Tara. (2018). The effect of problem based learning and teams games tournament model to improve competencies. Jurnal pendidikan Teknologi dan Kejuruan. 24(1), 137-146.

Eeliana, V., Sari, Y., Permata, A. (2019). Pengaruh model numbered head together (NHT) berbantu media roda putar terhadap prestasi belajar dan sikap kerja sama siswa kelas IV SDN 2 Ngampel Kulon. Konferensi Ilmiah Mahasiswa Unissula. 295-303

Fauzi, Moh. Fery. Buhun, Miftahul Fadliah. Purwadi, Agus. (2019). The Influence of Teams Games Tournament (TGT) toward Students' Interest in Arabic Language Learning. Izdihar. 2019;2(2):135148 https://doi.org/10.22219/jiz.v2i2.9986

Hakim, S.A., \& Syofyan, H. (2017). Pengaruh model pembelajaran kooperatif tipe teams games tournament (TGT) terhadap motivasi belajar IPA di kelas 4 SDN Kelapa dua 06 pagi Jakarta Barat. International Journals of Elementary Education, 1(4), 249-263.

Hikmah, Msy., Anwar, Y., Riyanto. (2018). Penerapan model pembelajaran teams games tournament (TGT) terhadap motivasi dan hasil belajar pada peserta didik pada materi dunia hewan kelas X di SMA Unggul Negeri 8 Palembang. Jurnal Pembelajaran Biologi. 5(1), 46-56.

Khohar, Moh. Adnan. Ruminiati, Ruminiati, Munzil,Munzil.(2016).Penerapan Teams Games Tournament Untuk Meningkatkan Hasil Belajar IPS Kelas IV SDN Blabak 1 Kandat Kediri. Jurnal Pendidikan: Teori, Penelitian, dan Pengembangan. 1(9) https://doi.org/10.17977/jp.v1i9.6864

Khuzaimah, Siti. Rohaeti, Eli.(2016) Pengembangan Perangkat Pembelajaran Integrated Science Berbasis Kearifan Lokal. Jurnal Pendidikan Matematika dan Sains. 4(2):110-119 https://doi.org/10.21831/jpms.v4i2.12920

Komarudin, Komarudin. (2018). The Improvement Activities and The Learning Result of Social Subject with Cooperative Learning Model of Teams Games Tournament Type At The Eight Grade of SMP Negeri 9 Metro. Jurnal Promosi Program Studi Pendidikan Ekonomi. 6(2). https://doi.org/10.24127/pro.v6i2.1692

Kurniawati, F., Gunansyah, G. (2019). Semanggi suroboyo Desa Kendung-Benowo Suroboyo sebagai sumber belajar berbasis etnopedagogi di Sekolah dasar. JPGSD. 7(3), 3061-3070.

Lestari, W.A., Lianah., Hidayat, S. (2019). Pengembangan modul pembelajaran biologi berbasis kearifan lokal di kawasan Wisata Goa Kreo pada materi ekosistem kelas x SMA. Jurnal Phenomenon. 9(1), 19.

Listyarini, Dwi Wahyu. As'ari, Abdur Rahman, Furaidah, Furaidah. (2018). Pengaruh Model Teams Games Tournament Berbantuan Permainan Halma terhadap Minat dan Hasil Belajar pada Materi Bunyi Siswa Kelas IV Sekolah Dasar. Jurnal Pendidikan: Teori, Penelitian, dan Pengembangan. 3(5) https://doi.org/10.17977/jptpp.v3i5.10930

Nisak, F., Isnawati., Trimulyono, G. (2016). Pengembangan permainan Question Wheel sebagai media pembelajaran untuk melatih keaktifan menjawab dan meningkatkan hasil belajar siswa pada materi jamur. Berkala Ilmiah Pendidikan Biologi. 5(3), 271-276.

Purwanto. 2010. Evaluasi Hasil Belajar. Yogyakarta: Pustaka Belajar.

Ramdani. Emi. (2018) Model Pembelajaran Kontekstual Berbasis Kearifan Lokal sebagai Penguatan Pendidikan Karakter. JUPIIS (Jurnal Pendidikan Ilmu-Ilmu Sosial). 10(1):1-10 https://doi.org/10.24114/jupiis.v10i1.8264

Rochanah, S., Damayani, A.T., Aniq, M. (2018). Pengaruh model teams games tournament (TGT) berbantu media flash card terhadap hasil belajar IPS siswa kelas III SDN Kalibalik 3 Kecamatan Banyuputih Kabupaten Batang. Jurnal Guru Kita. 2(3), 21-29.

Shoimin, Aris. 2014. Model Pembelajaran Inovatif dalam Kurikulum 2013. Yogyakarta: Ar-Ruzz Media.

Sholeh, Dwi Rohman. Waluyo, Herman J. Sudikan, Setya Yuwana. Wardani Nugraheni Eko. (2019). Implementasi Model Pembelajaran Drama Dengan Strategi Teams Games Tournament (Tgt) 
Berbasis Dongkrek. Dialektika: Jurnal Bahasa, Sastra, dan Pendidikan Bahasa dan Sastra Indonesia. 6(1):1-12. https://doi.org/10.15408/dialektika.v6i1.9679

Slavin Robert E. 2015. Cooperative Learning: teori, riset dan praktik. Bandung: NusaMedia

Suaeb, Suciyani. Degeng, I Nyoman Sudana. Amirudin, Achmad. (2017). Meningkatkan Hasil Belajar IPS Siswa Kelas V melalui Penerapan Pembelajaran Kooperatif Model Teams Games Tournament (TGT) Berbantuan Media Tebak Gambar. Jurnal Pendidikan: Teori, Penelitian, dan Pengembangan. 3(1). https://doi.org/10.17977/jptpp.v3i1.10435

Suardi, Moh. 2012. Pengantar Pendidikan dan Teori Aplikasi. Jakarta: indeks

Suastra, I.W., Tika, K., Kariasa, N. (2011). Efektivitas model pembelajaran sains berbasis budaya lokal untuk mengembangkan kompetensi dasar sains dan nilai kearifan lokal di SMP. JPPP Lemlit. 5(3), $258-273$.

Suryani, Nunuk, dan leo Agung. 2012.Startegi Belajar Mengajar. Yogyakarta: Ombak

Syarani, Rosi Novisa. (2019). Efektivitas Model Pembelajaran Kooperatif Tipe Teams Games Tournaments dalam Peningkatan Kemampuan Kanji (Studi Eksperimen Murni terhadap Mahasiswa Semester 4 STBA JIA Bekasi. Chi'e: Jurnal Pendidikan Bahasa Jepang.7(2):82-90 https://doi.org/10.15294/chie.v7i2.34094

Utami, Fitria. Sulasmono, Bambang Suteng. Setyaningtyas, Eunice Widyanti. (2019). Upaya Meningkatkan Hasil Belajar Matematika Melalui Penerapan Model Pembelajaran Teams Games Tournaments Berbantuan Media Papan Jaring Baku Siswa Kelas V. Jurnal Basicedu. 3(2):326-335 https://doi.org/10.31004/basicedu.v3i2.10

Wachida, Kemil., Wardana, M.D.K. (2014). Desain pembelajaran sekolah dasar berbasis kearifan lokal di kawasan pertambakan Kabupaten Sidoarjo. Jurnal Pendidikan Dasar. 156-165. doi.org/10.21009/JPD.091.14

Widayanti, E.R., Slameto. (2016). Pengaruh penerapan metode teams games tournament berbantuan permainan dadu terhadap hasil belajar IPA. Scholaria. 6(3), 182-195.

Widhiastuti, Ratieh. Fachrurrozie, Fachrurrozie. (2014).Teams Games Tournament (TGT) Sebagai Metode Untuk Meningkatkan Keaktifan Dan Kemampuan Belajar. Dinamika Pendidikan.9(1) https://doi.org/10.15294/dp.v9i1.3355

Wulandari, F.E., Regina, L.D.A. (2014). Pengaruh model kooperatif tipe TGT teams games tournament terhadap hasil beljar IPA SD. Widyagogik. 2(1), 37-41.

Yunanada, H., Advinda, L., Sumarmin, R. (2018). Effects of Cooperative Learning Model Type Games Teams Tournament (TGT) and Entry Behavior Student to Learning Competence Class XI IPA SeniorHigh School 1 Lengayang. International Journals of Sciences and High Technologies. 6(2), 329-339. 